\title{
Cold hardiness and biochemical response to low temperature of the unfed bush tick Haemaphysalis longicornis (Acari: Ixodidae)
}

\author{
Zhi-Jun Yu ${ }^{1+}$, Yu-Lan Lu ${ }^{1,2+}$, Xiao-Long Yang ${ }^{1}$, Jie Chen ${ }^{1}$, Hui Wang ${ }^{1}$, Duo Wang ${ }^{1}$ and Jing-Ze Liu ${ }^{1 *}$
}

\begin{abstract}
Background: The survival of overwintering ticks, is critical for their subsequent population dynamics in the spring, and consequent transmission of tick-borne diseases. Survival is largely influenced by the severity of the winter temperatures and their degree of cold hardiness at the overwintering stage. The bush tick Haemaphysalis longicornis, is widely distributed in China, and can transmit various pathogens that pose serious medical/veterinary problems. In the present study we investigated the effect of low temperature stress to tick survival, super-cooling point and body content of water, glycerol and total protein.

Methods: After various temperature acclimations, the super-cooling point was measured by $\mathrm{Ni} / \mathrm{CrNi}$-thermocouples with a precision temperature recorder. Water content was determined from weight loss of the sample exposed to $60^{\circ} \mathrm{C}$ for 48 h. Glycerol content was determined using Free Glycerol Reagent as directed by the manufacturer, and total protein was determined using the Bradford assay.

Results: The $50 \%$ mortality temperatures for the adults and nymphs were $-13.7^{\circ} \mathrm{C}$ and $-15.2^{\circ} \mathrm{C}$, respectively; and the discriminating temperatures for the adults and nymphs were $-16.0^{\circ} \mathrm{C}$ and $-17.0^{\circ} \mathrm{C}$, respectively. The super-cooling points of the adults and nymphs were $-19.0^{\circ} \mathrm{C}$ and $-22.7^{\circ} \mathrm{C}$, respectively. The water content of adult $\mathrm{H}$. longicornis decreased substantially after acclimation at $0^{\circ} \mathrm{C}$ for $10 \mathrm{~d}$, whereas the nymphs decreased after acclimation at $0^{\circ} \mathrm{C}$ for 20 $\mathrm{d}$, and the glycerol and proteins of both nymphs and adults were significantly increased $(p<0.01)$ when stressed at $0^{\circ} \mathrm{C}$ for $10 \mathrm{~d}$.
\end{abstract}

Conclusions: In H. longicornis, low temperature stress can enhance its cold hardiness and trigger appropriate responses, including reducing water content, and increasing glycerol and total protein content.

Keywords: Super-cooling capacity, Cold hardiness, Acclimation, Haemaphysalis longicornis

\section{Background}

Many overwintering arthropods, including mites and ticks, are threatened with death by the low temperatures that occur during mid-winter in temperate and cold regions $[1,2]$. Most of them employ various techniques to improve their cold hardiness under low-temperature conditions $[3,4]$. Some enter diapause, which may or may not increase cold hardiness [5]. Ticks, as obligate blood sucking ectoparasites of terrestrial vertebrates, are widely distributed

\footnotetext{
* Correspondence: jzliu21@heinfo.net

${ }^{\dagger}$ Equal contributors

'Key Laboratory of Animal Physiology, Biochemistry and Molecular Biology of Hebei province, College of Life Sciences, Hebei Normal University,

Shijiazhuang, Hebei 050016, China

Full list of author information is available at the end of the article
}

on every continent. They transmit a greater variety of pathogens (viruses, bacteria, rickettsiae, helminths and protozoa) than even mosquitoes [6]. However, the development and survival of ticks are largely dependent on the complex combination of environmental temperature and other climate variables [7]. The survival of overwintering ticks is obviously critical for their subsequent population dynamics in the spring [8]. Before the arrival of winter, ticks adopt behaviors and physiological adjustments to promote overwintering. These include searching for suitable habitation sites under leaf litter or stones [9], entering diapause, and increasing the concentration of cryprotectants like sorbitol, glycerol and various antifreeze proteins [10]. Previous investigations focused on the super-cooling 
capacity and cold hardiness of ticks [11-14] demonstrating that most ticks if not all, were as freeze-intolerant as many other arachnids. However, they did show a high potential super-cooling, irrespective of their geographical origin [12]. The bush tick Haemaphysalis longicornis, is the major vector of Theileria spp., Coxiella burnetti [15,16], Babesia sp. [17], Anaplasma phagocytophilum [18] and a suspected vector of the notorious bunyavirus, which has caused many deaths in China [19], Japan and Korea recently [20]. H. longicornis is endemic to north China [21], Australia, New Zealand, Korea and Japan [22,23], and can cause severe damage to human health and livestock production. In the field, H. longicornis completes one generation per year with some population overlap between developmental stages. Most survive the cold winter as nymphs under the leaf litter, with a small overwintering population of adults surviving on the host without feeding or under the leaf litter [24]. However, little is known about the physiological responses, and biochemical changes in unfed $H$. longicornis when exposed to low temperatures in winter.

In this study, H. longicornis individuals were cold acclimated to a series of low temperatures, and the survival rate, super-cooling capacity, and changes in water content, glycerol content and total protein were determined.

\section{Methods}

\section{Collection and rearing of ticks}

All ticks used in this study originated from adult $H$. longicornis collected from vegetation by blanket dragging in Xiaowutai National Nature Reserve Area $\left(39^{\circ} 50^{\prime}\right.$ to $40^{\circ} 07^{\prime} \mathrm{N}, 114^{\circ} 47^{\prime}$ to $115^{\circ} 30^{\prime} \mathrm{E}$ ) of Hebei province, north China. Colonies of these ticks were fed on rabbits as described by Liu et al. [25], and maintained in our laboratory incubator $\left(26 \pm 1^{\circ} \mathrm{C}, 85 \pm 5 \% \mathrm{RH}, 6: 18\right.$ (L:D)). Wild caught ticks were reared for two generations in the laboratory, with unfed nymphs ( 2 weeks after moulting) and adults (8 weeks following moulting) that within normal body-weight ranges randomly selected for the assays described in this study.

\section{Low temperature survival of unfed nymphs and adults}

To determine the temperature resulting in $50 \%$ mortality (LT50) and the discriminating temperature (the temperature resulting in $\sim 15-20 \%$ survival), which is important for testing the response of the rapid cold acclimation [26] of the unfed nymphal and adult $H$. longicornis, the survival of the ticks following a brief period of acclimation $(2 \mathrm{~h}$ ) was recorded and calculated as follows. Unfed nymphs or adults were randomly selected and placed in separate plastic vials (each vial contained 20 ticks, and each experiment was replicated 3 times) and used for each temperature treatment. The vials were transferred from the colony incubator $\left(26 \pm 1^{\circ} \mathrm{C}, 85 \pm 5 \% \mathrm{RH}, 6: 18\right.$ (L:D)) to a series of low temperature conditions (ranging from $-6^{\circ} \mathrm{C} \sim-22^{\circ} \mathrm{C}$, $1^{\circ} \mathrm{C}$ intervals, 6:18 (L:D)). After $2 \mathrm{~h}$ exposure to each low temperature, each group of ticks was immediately returned to the colony incubator. The percent survival at each temperature was recorded after $24 \mathrm{~h}$ recovery in the colony incubator, and the ticks that were able to coordinate their movements were recognized as survivors. The survival rate of ticks that were not exposed to low temperature (i.e. those kept in the colony incubator) served as the control.

\section{Effects of short term acclimation of nymphs to various temperatures}

To determine the effects of rapid cold acclimation, unfed nymphs (20 per group) were confined to plastic vials covered with gauze, and transferred from the colony incubator directly to an incubator set to $-3^{\circ} \mathrm{C}, 0^{\circ} \mathrm{C}, 5^{\circ} \mathrm{C}$, $10^{\circ} \mathrm{C}, 15^{\circ} \mathrm{C}$ or $20^{\circ} \mathrm{C}(85 \pm 5 \% \mathrm{RH}, 6 \mathrm{~L}: 18 \mathrm{D})$. Ticks were held at the selected temperature for $1 \mathrm{~h}, 2 \mathrm{~h}, 3 \mathrm{~h}$ or $4 \mathrm{~h}$, respectively, and then transferred to their discriminating temperature, which was determined in the section just above, and chilled for $2 \mathrm{~h}$. After this, all ticks were returned to the colony incubator $\left(26 \pm 1^{\circ} \mathrm{C}, 85 \pm 5 \% \mathrm{RH}\right.$, 6:18 (L:D)) and held for $24 \mathrm{~h}$. Survival rate was then assessed as described above. Controls were ticks transferred directly from the colony incubator to their discriminating temperature.

\section{Cold hardiness of adult and nymphal $H$. longicornis}

The cold hardiness of nymphal and adult $H$. longicornis was evaluated by exposing the ticks to a range of temperatures for $48 \mathrm{~h}$ and recording their survival. Each sample consisted of 50 nymphs or adults (without sex determination) kept in a glass tube with a cotton plug. Groups of ticks were put into a freezer, or incubator, and exposed to a constant temperature. All temperatures between $-20^{\circ} \mathrm{C}$ and $+20^{\circ} \mathrm{C}$ were tested, at $5^{\circ} \mathrm{C}$ intervals. Temperature fluctuations inside the test tubes did not exceed $\pm 0.5^{\circ} \mathrm{C}$, as measured by $\mathrm{Ni} / \mathrm{CrNi}$-thermocouples with a precision temperature recorder (Jiangsu Senyi Developmental Company, China). After 48 h of exposure, the ticks were returned to the colony incubator for $24 \mathrm{~h}$, and then examined to determine survival. The experiment was conducted in triplicate.

\section{Determination of the super-cooling point for unfed nymphs and adults}

Short and long term acclimation was achieved as follows. For short term acclimation, randomly selected unfed nymphal and adult $H$. longicornis were transferred from the colony incubator and exposed to fixed temperatures of $0^{\circ} \mathrm{C}$ or $5^{\circ} \mathrm{C}$ for $2 \mathrm{~h}$ to cold shock the ticks. For the long term acclimation, both unfed nymphal and adult ticks were exposed to $0^{\circ} \mathrm{C}$ for $10 \mathrm{~d}$ or $20 \mathrm{~d}$. The super-cooling point of the nymphal and adults ticks was 
determined by attaching $\mathrm{Ni} / \mathrm{CrNi}$-thermocouples to their dorsal surface using paraffin wax. The tick-thermocouple arrangements were fixed inside polyethylene tubes, which were then placed into an aluminum cooling block. The cooling block was then transferred to a refrigerated circulating bath (Thermo Scientific NESLAB RTE-740, USA). The temperature was decreased at a rate of $0.5^{\circ} \mathrm{C} / \mathrm{min}$, from an initial temperature of $26^{\circ} \mathrm{C}$. The body temperatures of the ticks were recorded at $1 \mathrm{~s}$ intervals using a precision temperature recorder (Jiangsu Senyi Developmental Company, China). The super-cooling point was defined as the lowest body temperature reached prior to the formation of ice crystals in the body. This point could be seen as a small peak on a scatter plot graph of the recoded data, which indicates the heat released during the phase change and means of the emission of the exotherm [27]. A minimum of 30 ticks were used in each group for super-cooling point determination.

\section{Changes in water content, glycerol and total protein of ticks after short and long term acclimation}

To induce short and long term acclimation, groups of unfed ticks (100 nymphs or 50 adults) were selected such that the initial mean weight did not differ statistically between the groups. They were exposed to $0^{\circ} \mathrm{C}$ for $2 \mathrm{~h}, 5^{\circ} \mathrm{C}$ for $2 \mathrm{~h}, 0^{\circ} \mathrm{C}$ for $10 \mathrm{~d}$ or $0^{\circ} \mathrm{C}$ for $20 \mathrm{~d}$ before determining the content of water, glycerol and total protein.

After short and long term acclimation, the ticks were tested for survival, weighed, dried for $48 \mathrm{~h}$ at $60^{\circ} \mathrm{C}$, and their dry weights were recorded. Preliminary experiments determined that no further weight loss occurred beyond $48 \mathrm{~h}$. The water content was calculated for each tick based on its weight loss. To determine the amount of glycerol and proteins, adult and nymphal frozen ticks were crushed and homogenized in $1 \mathrm{~mL}$ phosphate buffered saline (PBS, $0.01 \mathrm{~mol} / \mathrm{L}, \mathrm{pH} 7.4$ ), and the homogenates were centrifuged at $10,000 \mathrm{rpm}$ for $15 \mathrm{~min}$ in $4^{\circ} \mathrm{C}$. The pelleted fraction was cleaned using $0.5 \mathrm{~mL}$ PBS, re-centrifuged, and the supernatant combined with that from the previous centrifugation. Glycerol concentrations were assayed using Free Glycerol Reagent (Sigma-Aldrich) according to the manufacturer's protocol. Protein content was determined by Bradford assay [28] with absorbance measured at $595 \mathrm{~nm}$.

\section{Statistical analysis}

Statistical analysis was performed using STATISTICA Version 6.0 (StatSoft, Inc., Tulsa, OK, U.S.A.). All parametric data comparisons were performed by one-way analysis of variance (ANOVA) and probit analysis was used to calculate the LT50.

\section{Ethical approval}

All the experiments were approved by the Animal Ethics Committee of Hebei Normal University.

\section{Results}

Survival of ticks held at low temperatures

After cold shocking ticks for $2 \mathrm{~h}$ over a range of subzero temperatures, the survival rate gradually declined, corresponding to the decrease in temperature, beginning at $-8^{\circ} \mathrm{C}$ and $-10^{\circ} \mathrm{C}$ for adults and nymphs respectively (Figure 1). None of the adults survived at $-20^{\circ} \mathrm{C}$, and all the nymphs died at $-21^{\circ} \mathrm{C}$. Nymphs held at $-13^{\circ} \mathrm{C},-15^{\circ} \mathrm{C}$ or $-17^{\circ} \mathrm{C}$ had survival rates of $91.5 \%, 58.2 \%$, and $19.6 \%$, respectively. Survival rate of the adults at $-11^{\circ} \mathrm{C},-14^{\circ} \mathrm{C}$ and $-16^{\circ} \mathrm{C}$ was $85.8 \%, 50.8 \%$ and $18.3 \%$, respectively (Figure 1 ). The $50 \%$ mortality temperature calculated for the adults and nymphs was $-13.7^{\circ} \mathrm{C}$ and $-15.2^{\circ} \mathrm{C}$, respectively. The discriminating temperature for the adults and nymphs was $-16.0^{\circ} \mathrm{C}$ and $-17.0^{\circ} \mathrm{C}$, respectively.

\section{Effects of short term acclimation of nymphs to cold temperatures}

Short term acclimation in nymphs was induced by acclimating at temperatures ranging from $-3^{\circ} \mathrm{C}$ to $20^{\circ} \mathrm{C}$ for a certain time $(1-4 \mathrm{~h})$, and then stressed at the discriminating temperature for $2 \mathrm{~h}$. The subsequent survival rate was significantly increased following cold acclimation at $-3^{\circ} \mathrm{C}$ $(p<0.05), 0^{\circ} \mathrm{C}(p<0.01), 5^{\circ} \mathrm{C}(p<0.01)$ and $10^{\circ} \mathrm{C}(p<0.05)$ for a period of $1 \mathrm{~h}, 2 \mathrm{~h}, 3 \mathrm{~h}$ or $4 \mathrm{~h}$, compared to the nonacclimated control group $(20.3 \pm 2.9 \%)$ (Figure 2$)$. Maximal enhancement of cold tolerance was induced by acclimation to $0^{\circ} \mathrm{C}$ and $5^{\circ} \mathrm{C}$, while acclimation at $15^{\circ} \mathrm{C}(p<0.05)$ and $20^{\circ} \mathrm{C}(p<0.05)$ for $3 \mathrm{~h}$ or $4 \mathrm{~h}$ could also enhance their cold tolerance (Figure 2).

\section{Cold hardiness of $\boldsymbol{H}$. longicornis}

The cold hardiness of $H$. longicornis was evaluated by calculating the survival rate of the ticks treated at a series of temperatures for $48 \mathrm{~h}$. When exposed to temperatures at or above $0^{\circ} \mathrm{C}, 100 \%$ of the acclimated adult ticks survived, compared to $73 \%$ of nymphs. Nymphal mortality increased gradually as temperatures decreased

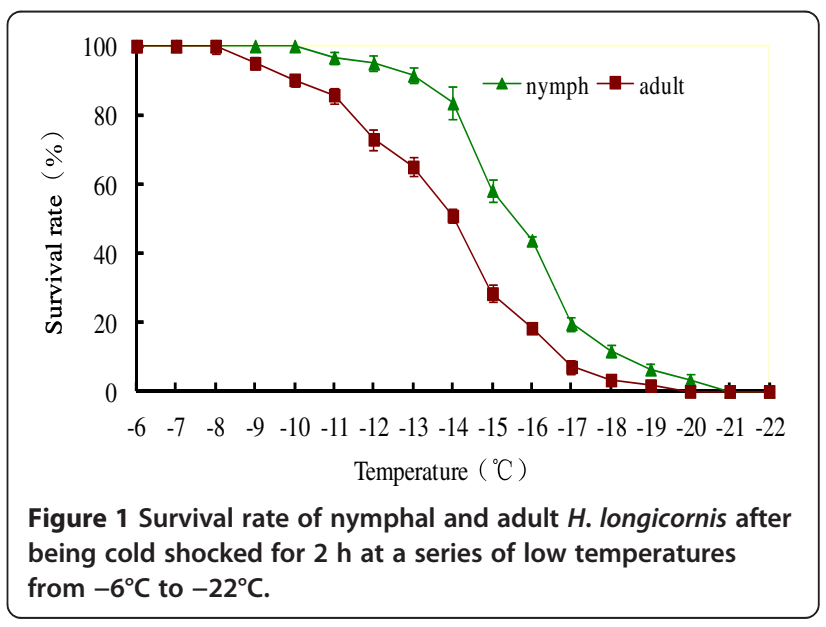



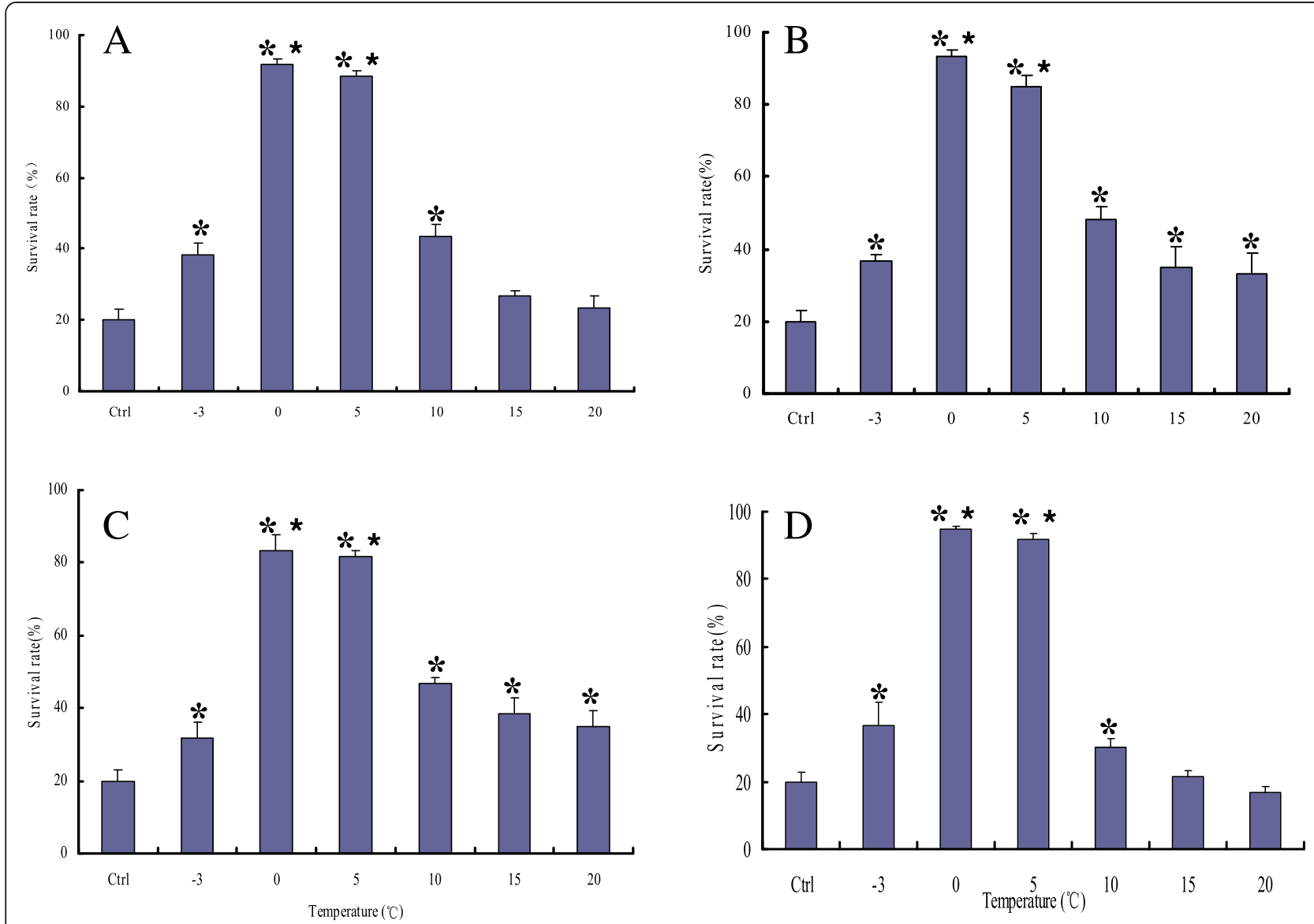

Figure 2 Survival rate of nymphal $\boldsymbol{H}$. longicornis after being cold acclimated for a certain time and stressed at the discriminating temperature. A: acclimate for $1 \mathrm{~h}$; $\mathbf{B}$ : acclimate for $2 \mathrm{~h}$; C: acclimate for $3 \mathrm{~h}$; $\mathbf{D}$ : acclimate for $4 \mathrm{~h}$. The different superscripts indicates statistical difference, ${ }^{*} p<0.05,{ }^{* *} p<0.01$. Ctrl: Control group.

from $15^{\circ} \mathrm{C}$ to $-10^{\circ} \mathrm{C}$, whereas adult survival began to decrease at temperatures less than $-5^{\circ} \mathrm{C}$ (Figure 3). The survival of nymphs was higher than that of adults when held at $-15^{\circ} \mathrm{C}(p<0.05)$. No ticks survived after being held at $-20^{\circ} \mathrm{C}$.

\section{Super-cooling capacity of $H$. longicornis}

The super-cooling points of the nymphs and adults were $-22.7 \pm 1.4^{\circ} \mathrm{C}$ and $-19.0 \pm 3.7^{\circ} \mathrm{C}$, respectively. In short term acclimation, the super-cooling point of nymphs that had been cold acclimated at $0^{\circ} \mathrm{C}(p<0.05)$

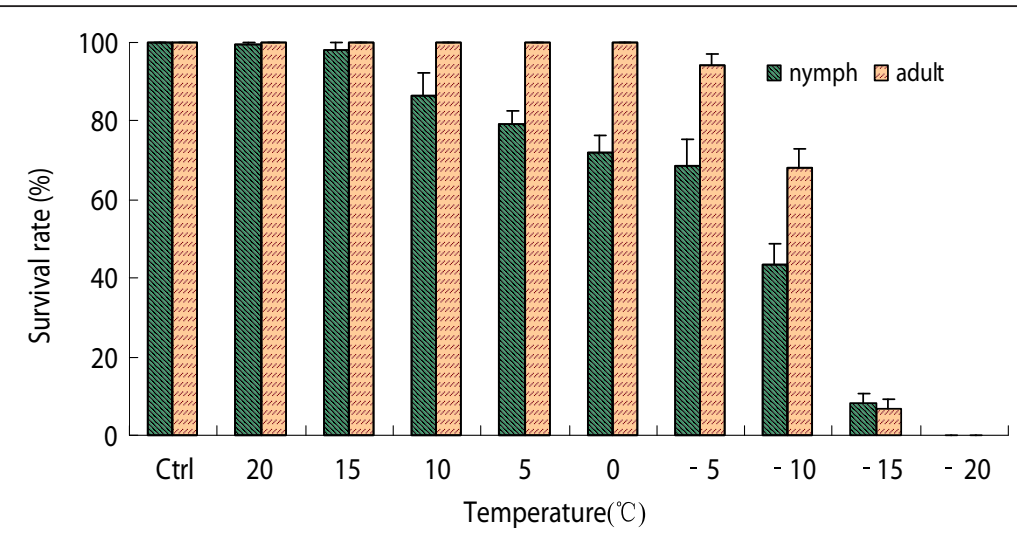

Figure 3 The survival rate of $H$. longicornis after direct exposure to a series of low temperatures for $48 \mathrm{~h}$. 
or $5^{\circ} \mathrm{C}(p<0.05)$ for $2 \mathrm{~h}$, was significantly lower than that of the control group (Table 1). There were no significant differences between the groups acclimated at $0^{\circ} \mathrm{C}$ or $5^{\circ} \mathrm{C}$ for $2 \mathrm{~h}(p>0.05)$. For the long-term acclimation, nymphs that had been cold acclimated at $0^{\circ} \mathrm{C}$ for $20 \mathrm{~d}$ had a significantly lower super-cooling point compared to the control group $(p<0.05)$. However, there was no difference between the control group and those nymphs acclimated for only $10 \mathrm{~d}(p>0.05$; Table 1$)$.

When compared to the controls, the super-cooling point of the adults acclimated at $0^{\circ} \mathrm{C}(p<0.01)$ or $5^{\circ} \mathrm{C}(p<0.01)$ for $2 \mathrm{~h}$ was significantly lower. For the long-term acclimation, the super-cooling point of the adults acclimated at $0^{\circ} \mathrm{C}$ for $10 \mathrm{~d}$ or $20 \mathrm{~d}$ was significantly lower compared to the non-acclimated controls (Table 2).

\section{Changes in water content, glycerol and total protein of nymphal and adult $\boldsymbol{H}$. longicornis}

Changes in water content, glycerol and total protein of nymphal $H$. longicornis were determined after a series of cold temperature treatments, and results indicated that the water content of nymphs increased significantly after acclimation at $5^{\circ} \mathrm{C}$ for $2 \mathrm{~h}(p<0.01)$, and significantly decreased in nymphs held at $0^{\circ} \mathrm{C}$ for $20 \mathrm{~d}(p<0.01)$. There were no significant changes in nymphs acclimated at $0^{\circ} \mathrm{C}$ for $2 \mathrm{~h}(p>0.05)$ or at $0^{\circ} \mathrm{C}$ for $10 \mathrm{~d}(p>0.05)$ (Table 1$)$. The glycerol content of nymphs that were acclimated at $0^{\circ} \mathrm{C}$ for $10 \mathrm{~d}$ or $20 \mathrm{~d}$ was significantly increased compared to both the non-acclimated control group and the other low temperature treatments $(p<0.01$; Table 1$)$, and no significant changes were observed when treated at $0^{\circ} \mathrm{C}$ or $5^{\circ} \mathrm{C}$ for $2 \mathrm{~h}$. The protein content of nymphs significantly increased following acclimation at $0^{\circ} \mathrm{C}$ for $10 \mathrm{~d}$ when compared with that of the control group $(p<0.01)$, but decreased significantly when acclimated at $0^{\circ} \mathrm{C}$ for $20 \mathrm{~d}(p<0.01)$. There was no increase in the protein content of nymphs acclimated at $0^{\circ} \mathrm{C}$ or $5^{\circ} \mathrm{C}$ for $2 \mathrm{~h}$ $(p>0.05)$ (Table 1).

As for the adults, water content increased significantly in the nymphs following acclimation at $0^{\circ} \mathrm{C}(p<0.01)$ or $5^{\circ} \mathrm{C}$ for $2 \mathrm{~h}(p<0.01)$, but decreased significantly in those ticks acclimated at $0^{\circ} \mathrm{C}$ for $10 \mathrm{~d}(p<0.01)$ or $20 \mathrm{~d}$ $(p<0.01)$ (Table 2). The glycerol content increased significantly after acclimation at $0^{\circ} \mathrm{C}$ for $10 \mathrm{~d}$ or for $20 \mathrm{~d}$ compared to both the non-acclimated control group and the other low temperature treatments $(p<0.01$; Table 2), and no significant changes were detected from the adults held at $0^{\circ} \mathrm{C}$ or $5^{\circ} \mathrm{C}$ for $2 \mathrm{~h}$ when compared to controls $(p>0.05)$ (Table 2). Adults acclimated at $0^{\circ} \mathrm{C}$ for $10 \mathrm{~d}(p<0.01)$ contained significantly more protein than controls, but those adults acclimated at $0^{\circ} \mathrm{C}$ and $5^{\circ}$ $\mathrm{C}$ for $2 \mathrm{~h}$ exhibited decreased protein content $(p<0.05)$. Acclimation at $0^{\circ} \mathrm{C}$ for $20 \mathrm{~d}$ had no effect on the protein content of adults $(p>0.05)$ (Table 2).

\section{Discussion}

We demonstrate here that nymphal and adult $H$. longicornis are freeze-susceptible [11,12,14,29,30]. Nymphal $H$. longicornis are slightly more cold-hardy than the adults, the LT50 being $-15.2^{\circ} \mathrm{C}$ and $-13.7^{\circ} \mathrm{C}$, respectively (Figure 1). Similarly, the discriminating temperature for the adults and nymphs was $-16.0^{\circ} \mathrm{C}$ and $-17.0^{\circ} \mathrm{C}$, respectively, all indicating that nymphs have a slightly broader range of tolerance. A possible explanation could be related to the smaller body size of the nymphs, and this was consistent with our previous work that nymphal and adult $H$. longicornis are able to survive overwinter in the field [24].

The super-cooling point of the nymphs $\left(-22.7^{\circ} \mathrm{C}\right)$ was lower than that of the adults $\left(-19.0^{\circ} \mathrm{C}\right.$; Tables 1 and 2$)$. A similar situation pertains to several other tick species [14,29-32]. Although the super-cooling point seems to have no predictive value for any tick species in an ecological context, it does represent the lower temperature limit for survival [14]. In the current work, both shortand long-term acclimation decreased the super-cooling point, indicating that cold acclimation in the months prior to the onset of winter may be adaptive for winter survival in the field.

Low temperature acclimation lowers the super-cooling point in many other arthropods like Pieris brassicae [33] and Monochamus alternatus [34], and within a limited range, the lower the temperature, the greater the resulting cold hardiness. In the current study, after cold acclimated at $0^{\circ} \mathrm{C}$ or $5^{\circ} \mathrm{C}$ for $2 \mathrm{~h}$, the super-cooling point of

Table 1 The physiological and biochemical responses of nymphal $\boldsymbol{H}$. longicornis after low-temperature treatments

\begin{tabular}{lccccc}
\hline \multirow{2}{*}{ Treatment } & \multicolumn{4}{c}{ Physiological and biochemical response (nymph) } \\
\cline { 2 - 6 } & Survival rate (\%) & Super-cooling point $\left({ }^{\circ} \mathrm{C}\right)$ & Water $(\%)$ & Glycerol $(\boldsymbol{\mu g} / \mathbf{m L})$ & Protein $(\boldsymbol{\mu g} / \mathbf{m L})$ \\
\hline Control & $100 \pm 0.0$ & $-22.7 \pm 1.4$ & $57.6 \pm 1.0$ & $2.6 \pm 0.1$ & $68.2 \pm 7.9$ \\
$0^{\circ} \mathrm{C} 2 \mathrm{~h}$ & $100 \pm 0.0$ & $-23.8 \pm 0.9^{*}$ & $59.3 \pm 1.6$ & $2.9 \pm 1.1$ & $53.9 \pm 12.7$ \\
$5^{\circ} \mathrm{C} 2 \mathrm{~h}$ & $100 \pm 0.0$ & $-24.0 \pm 1.4^{*}$ & $64.8 \pm 1.1^{* *}$ & $2.9 \pm 0.3$ & $61.0 \pm 8.6$ \\
$0^{\circ} \mathrm{C} 10 \mathrm{~d}$ & $62.4 \pm 5.6$ & $-23.3 \pm 1.4$ & $54.7 \pm 2.2$ & $4.2 \pm 0.1^{* *}$ & $112.5 \pm 4.6^{* *}$ \\
$0^{\circ} \mathrm{C} 20 \mathrm{~d}$ & $54.3 \pm 7.8$ & $-23.7 \pm 1.1^{*}$ & $50.3 \pm 1.6^{* *}$ & $3.5 \pm 0.3^{* *}$ & $21.8 \pm 6.6^{* *}$ \\
\hline
\end{tabular}

${ }^{*} p<0.05,{ }^{* *} p<0.01$. 
Table 2 The physiological and biochemical responses of adult $\boldsymbol{H}$. longicornis after low-temperature treatments

\begin{tabular}{lccccc}
\hline \multirow{2}{*}{ Treatment } & \multicolumn{4}{c}{ Physiological and biochemical response (adult) } \\
\cline { 2 - 6 } & Survival rate (\%) & Super-cooling point $\left({ }^{\circ} \mathrm{C}\right)$ & Water $(\%)$ & Glycerol $(\boldsymbol{\mu g} / \mathbf{m L})$ & Protein $(\boldsymbol{\mu g} / \mathbf{m L})$ \\
\hline Control & $100 \pm 0.0$ & $-19.0 \pm 3.7$ & $56.7 \pm 0.6$ & $1.1 \pm 0.1$ & $29.8 \pm 2.3$ \\
$0^{\circ} \mathrm{C} 2 \mathrm{~h}$ & $100 \pm 0.0$ & $-19.8 \pm 2.7^{* *}$ & $63.3 \pm 1.4^{* *}$ & $1.0 \pm 0.1$ & $11.8 \pm 1.7^{*}$ \\
$5^{\circ} \mathrm{C} 2 \mathrm{~h}$ & $100 \pm 0.0$ & $-20.3 \pm 2.4^{* *}$ & $62.2 \pm 2.1^{* *}$ & $1.1 \pm 0.2$ & $10.8 \pm 4.8^{*}$ \\
$0^{\circ} \mathrm{C} 10 \mathrm{~d}$ & $98.2 \pm 0.7$ & $-20.7 \pm 2.3^{* *}$ & $49.6 \pm 3.4^{* *}$ & $3.1 \pm 0.4^{* *}$ & $59.3 \pm 9.8^{* *}$ \\
$0^{\circ} \mathrm{C}$ 20d & $96.5 \pm 1.2$ & $-21.3 \pm 1.8^{* *}$ & $48.4 \pm 1.0^{* *}$ & $4.4 \pm 0.6^{* *}$ & $20.0 \pm 4.8$ \\
\hline
\end{tabular}

${ }^{*} p<0.05,{ }^{* *} p<0.01$.

the nymphal and adult $H$. longicornis was decreased compared with the control group.

Although tick survival increased after short term acclimation, the changes in water, glycerol and total protein content were observed only after long-term cold acclimation (Tables 1 and 2). The cold tolerance of many arthropods results from an increase in various solutes [35-37]. However, some insects increase their freeze tolerance by losing water, whereas the opposite occurs in $H$. longicornis (Tables 1 and 2) and in D. variabilis and A. americanum ticks [8]. This may be attributed to quick water absorption just after the onset of low temperatures, which will hamper the desiccation in the subsequent long winter [38], and the observed water loss in the long time exposure of nymphal and adult $H$. longicornis in the current study may support this hypothesis. Additionally, glycerol and other low molecular weight substances may also protect against both desiccation and cold temperatures [39]. Although the water content of both nymphal and adult $H$. longicornis substantially decreased $(p<0.01)$ after acclimation at $0^{\circ} \mathrm{C}$ for $10 \mathrm{~d}$ or 20 $\mathrm{d}$, the increased levels of glycerol and protein content may act to increase the cold hardiness and reduce water loss in the overwintering stage.

Numerous proteins, including ice-nucleating agents and the antifreeze/thermal hysteresis proteins, enhance the cold hardiness of many arthropods [40]. However, not much is known about the cryoprotectants in ticks, although many stress response proteins have been identified from transcriptomics and proteomics data [41]. In the current study, short term acclimation had no effect on the protein content in nymphs, whereas in adults, the protein content declined slightly following rapid cold treatment. However, the protein content in both nymphal and adult $H$. longicornis increased significantly after acclimation at $0^{\circ} \mathrm{C}$ for $10 \mathrm{~d}$ (Tables 1 and 2 ), suggesting that cryoprotective proteins might be produced by this treatment. The main objective of this study was to extend our knowledge on the complexity of the physiological adjustments linked to the cold hardiness in $H$. longicornis. Further investigations are required to confirm and characterize the proteins produced during the acclimation phase.

\section{Conclusions}

The tick $H$. longicornis is freeze susceptible, and low temperature stress can enhance its cold hardiness and trigger a reduction in water content and increase in glycerol and proteins, suggesting that these serve as cryoprotectants.

\section{Competing interest}

The authors declare no conflicts of interest.

\section{Authors' contributions}

$Y Z-J, L Y-L$ and $L J-Z$ conceived and designed the study, carried out the temperature acclimation and determined the changes in water, glycerol and protein contents of the ticks, drafted the manuscript, and critically revised the manuscript. YX-L and CJ calculated the low temperature survival and measured the super-cooling points. Wang $\mathrm{H}$ and Wang $\mathrm{D}$ participated in sample collection, study implementation and data collection and helped to revise the manuscript. All authors read and approved the final manuscript.

\section{Acknowledgements}

We would like to thank Prof. W. Reuben Kaufman and Dr. Alexander Smith from the Department of Biological Sciences at the University of Alberta, Canada for English editing. This work was supported by National Natural Science Foundation of China (31272372), the Specialized Research Fund for the Doctoral Program of Higher Education of China (20131303130001), Natural Science Research Programs of Educational Department of Hebei Province (Q2012072), and Science Foundation of Hebei Normal University (L2012Z05; L2011B13).

\section{Author details}

${ }^{1}$ Key Laboratory of Animal Physiology, Biochemistry and Molecular Biology of Hebei province, College of Life Sciences, Hebei Normal University, Shijiazhuang, Hebei 050016, China. ${ }^{2}$ Department of Biology, Langfang Normal College, Langfang, Hebei 065000, China.

Received: 5 May 2014 Accepted: 15 July 2014

Published: 26 July 2014

\section{References}

1. Bale JS: Insects at low temperature: a predictable relationship. Funct Ecol 1991, 5:291-298.

2. Dantas-Torres F, Otranto D: Cold-stress response of engorged females of Rhipicephalus sanguineus. Exp Appl Acarol 2011, 54:313-318.

3. Brunner JL, Killilea M, Ostfeld RS: Overwintering survival of nymphal Ixodes scapularis (acari: ixodidae) under natural conditions. J Med Entomol 2012, 49:981-987.

4. Herrmann C, Gern L: Survival of Ixodes ricinus (acari: ixodidae) nymphs under cold conditions is negatively influenced by frequent temperature variations. Ticks Tick Borne Dis 2013, 4:445-451.

5. Denlinger DL: Relationship Between Cold Hardiness and Diapause. In Insects at Low Temperature. Edited by Lee RE, Denlinger DL. New York: Chapman and Hall; 1991. 
6. Austen JM, Ryan UM, Friend JA, Ditcham WGF, Reid SA: Vector of Trypanosoma copemani identified as Ixodes sp. Parasitology 2011, 138:866-872.

7. Estrada-Peňa A, Ayllón N, de la Fuente J: Impact of climate trends on tick-borne pathogen transmission. Front Physiol 2012, 3:1-12.

8. Hwang KLH: Physiological Diversity and Temperature Hardening in Adult Tick Dermacentor Variabilis (Acari: Ixodidae). Ph D Thesis: The Ohio State University; 2006.

9. Dantas-Torres F: Biology and ecology of the brown dog tick, Rhipicephalus sanguineus. Parasit Vectors 2010, 3:1-11.

10. Neelakanta G, Sultana H, Fish D, Anderson JF, Fikrig E: Anaplasma phagocytophilum induces Ixodes scapularis ticks to express an antifreeze glycoprotein gene that enhances their survival in the cold. J Clin Invest 2010, 120:3179-3190

11. Burks CS, Stewart J, Richard L, Needham GR, Lee RE Jr: The role of direct chilling injury and inoculative freezing in cold tolerance of Amblyomma americanum, Dermacentor variabilis and Ixodes scapularis. Physiol Entomol 1996, 21:44-50.

12. Dantel $H$, Knülle $W$ : The supercooling ability of ticks (acari, ixodoidea). J Comp Physiol B 1996, 166:517-524.

13. Stewart RL: Overwintering Ecology and Physiology of Amblyomma Americanum and Dermacentor Variabilis (Acari: Ixodidae) in Central Ohio Ph D Thesis: The Ohio State University; 1998.

14. Dörr B, Gothe R: Cold-hardiness of Dermacentor marginatus (acari: ixodidae). Exp Appl Acarol 2001, 25:151-169.

15. Lee JH, Park HS, Jang WJ, Koh SE, Park TK, Kang SS, Kim BJ, Kook YH, Park $\mathrm{KH}$, Lee $\mathrm{SH}$ : Identification of the Coxiella sp. detected from Haemaphysalis longicornis ticks in Korea. Microbiol Immunol 2004, 48:125-130.

16. Fujisaki K, Kawazu S, Kamio T: The taxonomy of the bovine Theileria spp. Parasitol Today 1994, 10:31-33.

17. Guan G, Moreau E, Liu J, Hao X, Ma M, Luo J, Chauvin A, Yin H: Babesia sp. BQ1 (lintan): molecular evidence of experimental transmission to sheep by Haemaphysalis qinghaiensis and Haemaphysalis longicornis. Parasitol Int 2010, 59:265-267.

18. Wu XB, Na RH, Wei SS, Zhu JS, Peng HJ: Distribution of tick-borne diseases in China. Parasit Vectors 2013, 6:119-127.

19. Yu X, Liang M, Zhang S, Liu Y, Li J, Sun Y, Zhang L, Zhang Q, Popov VL, Li C, Qu J, Li Q, Zhang Y, Hai R, Wu W, Wang Q, Zhan F, Wang X, Kan B, Wang S, Wan K, Jing H, Lu J, Yin W, Zhou H, Guan X, Liu J, Bi Z, Liu G, Ren J, et al: Fever with thrombocytopenia associated with a novel Bunyavirus in China. N Engl J Med 2011, 364:1523-1532.

20. Kim CM, Kim MS, Park MS, Park JH, Chae JS: Identification of Ehrlichia chaffeensis, Anaplasma phagocytophilum, and A. bovis in Haemaphysalis longicornis and Ixodes persulcatus ticks from Korea. Vector-Borne Zoonot Dis 2003, 3:17-26.

21. Chen Z, Yang $X, B$ B F, Yang $X$, Yang $X$, Liu J: Ticks (acari: ixodoidea: argasidae, ixodidae) of China. Exp Appl Acarol 2010, 51:393-404.

22. Hoogstraal H, Kaiser MN, Kohls GM: The subgenus persicargas (ixodoidea, argasidae, argas). 4. Argas ( $P$.) robertsi, new species, a parasite of Australian fowl, and keys to Australian argasid species. Ann Entomol SoC Am 1968, 62:535-539.

23. Tenquist JD, Charleston W: A revision of the annotated checklist of ectoparasites of terrestrial mammals in New Zealand. J Roy Soc New Zeal 2001, 31:481-542.

24. Zheng HY, Yu ZJ, Chen Z, Zhou LF, Zheng B, Ma H, Liu JZ: Development and biological characteristics of Haemaphysalis longicornis (acari: ixodidae) under field conditions. Exp Appl Acarol 2011, 53:377-388.

25. Liu J, Liu Z, Zhang Y, Yang X, Gao Z: Biology of Dermacentor silvarum (acari: ixodidae) under laboratory conditions. Exp Appl Acarol 2005 36:131-138

26. Powell SJ, Bale JS: Low temperature acclimated populations of the grain aphid Sitobion avenae retain ability to rapidly cold harden with enhanced fitness. J Exp Biol 2005, 208:2615-2620.

27. Carrillo MA, Cannon CA: Supercooling point variability in the Indian meal moth, Plodia interpunctella (Hübner) (Lepidoptera: pyralidae). J Stored Prod Res 2005, 41:556-564.

28. Bradford MM: A rapid and sensitive method for the quantization of microgram quantities of protein utilizing the principle of protein-dye binding. Anal Biochem 1976, 72:248-254.
29. Lee RE Jr, Baust JG: Cold-hardiness in the Antarctic tick. Ixodes uriae Physiol Zool 1987, 60:499-506

30. Dautel H, Knülle W: Cold hardiness, supercooling ability and causes of low-temperature mortality in the soft tick, Argas reflexus, and the hard tick, Ixodes ricinus (acari: ixodidae) from Central Europe. J Insect Physiol 1997, 43:843-854.

31. Needham GR, Jaworski DC, Chen CP, Lee RE: Cold-hardiness of a laboratory colony of lone star ticks (acari: ixodidae). J Med Entomol 1996, 33:706-710.

32. Stark U, Gothe R: Studies on the critical water mass, rehydration capability and potential, acute chill tolerance and supercooling point of Argas (Persicargas) walkerae (acari: ixodidae). Onderstepoort J Vet 2001, 68:11-20.

33. Pullin AS, Bale JS: Effects of low temperature on diapausing Aglais urticae and Inachis io (Lepidoptera: Nymphalidae): cold hardiness and overwintering survival. J Insect Physiol 1989, 35:277-281.

34. Ma RY, Hao SG, Tian J, Sun JH, Kang L: Seasonal variation in cold-hardiness of the Japanese pine sawyer Monochamus alternates (Coleoptera: cerambycidae). Environ Entomol 2006, 35:881-886.

35. Sømme L: Supercooling and winter survival in terrestrial arthropods. Comp Biochem Physiol A Physiol 1982, 73:519-543.

36. Kǒtál V: Cryoprotective role of polyols independent of the increase in supercooling capacity in diapausing adults of Pyrrhocoris apterus (Heteroptera: Insecta). Comp Biochem Physiol B: Biochem Mol Biol 2001, 130:365-374.

37. Worland MR: The relationship between water content and cold tolerance in the arctic collembola Onychiurus arcticus (Collembola: onychiuridae). Eur J Entomol 1996, 93:341-348.

38. Danks HY: The wider integration of studies on insect cold-hardiness. Eur J Entomol 1996, 93:383-403.

39. Sømme L: The physiology of cold hardiness in terrestrial arthropods. Eur J Entomol 1999, 96:1-10.

40. Ramløv H: Aspects of natural cold tolerance in ectothermic animals. Hum Reprod 2000, 15:26-46.

41. Villar M, Popara M, Ayllón N, de Mera IGF, Mateos-Hernández L, Galindo RC, Manrique $M$, Tobes $R$, de la Fuente J: A systems biology approach to the characterization of stress response in Dermacentor reticulatus tick unfed larvae. PloS One 2014, 9:e89564.

\section{doi:10.1186/1756-3305-7-346}

Cite this article as: Yu et al:: Cold hardiness and biochemical response to low temperature of the unfed bush tick Haemaphysalis longicornis (Acari: Ixodidae). Parasites \& Vectors 2014 7:346.

\section{Submit your next manuscript to BioMed Central and take full advantage of:}

- Convenient online submission

- Thorough peer review

- No space constraints or color figure charges

- Immediate publication on acceptance

- Inclusion in PubMed, CAS, Scopus and Google Scholar

- Research which is freely available for redistribution 